\title{
Nutritional quality of meals offered to children (kids' meals) at chain restaurants in Japan
}

\author{
Ken Uechi* \\ Division of Community Health Nursing, Faculty of Health Science, Toho University, 2-2-1 Miyama, Funabashi, Chiba \\ 274-8510, Japan
}

Submitted 7 March 2018: Final revision received 4 June 2018: Accepted 26 June 2018: First published online 15 August 2018

\begin{abstract}
Objective: To evaluate the nutritional quality, particularly the fat and salt contents, of meals offered to children (kids' meals) at chain restaurants in Japan.

Design: A web-based content analysis was conducted to evaluate the type of restaurant, type of meal, incentives, health claims and nutrition data of kids' meals. The nutritional appropriateness of kids' meals was assessed with the Standard for the School Lunch Program, which regulates energy ( $\leq 2218 \mathrm{~kJ})$, protein $(20-30 \mathrm{~g})$, fat $(\leq 30 \%$ of energy $(\mathrm{E} \%))$ and salt $(<2 \mathrm{~g})$ contents of the school lunch in Japan. Linear mixed models were employed for evaluating the relationship between the characteristics of kids' meals and their fat (E\%) or salt (g) content.

Setting: Restaurant websites providing nutritional data of kids' meals in Japan.

Subjects: A total of 438 kids' meals offered by forty-two chain restaurant brands from across twenty food-service companies.

Results: Overall, 58.9, 40.6 and $34.5 \%$ of the kids' meals were determined to be appropriate regarding their energy $(\leq 2218 \mathrm{~kJ})$, fat $(\leq 30 \mathrm{E} \%)$ and salt content $(<2 \mathrm{~g})$. In addition, $15.5 \%$ of kids' meals met the multiple standards of energy, fat and salt contents. 'Japanese-style' (restaurant-level characteristic) was associated with a decrease in the fat $\mathrm{E} \%$ of kids' meals $(\beta=-6 \cdot 2 ; 95 \% \mathrm{CI}-11 \cdot 0,-1 \cdot 4)$ and an increase in the salt content $(\beta=0.7 ; 95 \%$ CI $0.06,1 \cdot 3)$.

Conclusions: The characteristics of the restaurant-served kids' meals in Japan were high fat $\mathrm{E} \%$ and high salt content from different cultural contexts of the Western and the Japanese diet.
\end{abstract}

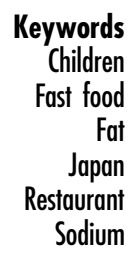

The regulation of adequate and optimal dietary intake for the progressive growth of children is a significant challenge, particularly considering the high prevalence of childhood overweight/obesity worldwide ${ }^{(1,2)}$. One factor possibly contributing to the present obesity epidemic and the rapid increase in the rate of obesity is the increased consumption of foods at restaurants, which includes fast foods, large meal portion sizes and high food energy densities $^{(3-5)}$.

Although the prevalence of obesity among Japanese schoolchildren is approximately $10 \%$ and has slightly decreased since the $2000 \mathrm{~s}^{(6,7)}$, the dietary intake at out-ofschool environments among Japanese children has been a possible cause of inappropriate nutritional intake linked not only with obesity but also CVD. A recent nationwide epidemiological study reported that the dietary intake on a typical day when school lunch is offered was associated with favourable nutrient quality, particularly concerning vitamin and mineral contents, as compared with those on non-school days ${ }^{(8)}$. In Japan, the school lunch is considered an integral component of the education programme. All children are provided the same menu under the regulation for the nutrient quality of school lunch (Standards for the School Lunch Program (SLP) $)^{(9)}$. Hence, they can learn about the well-balanced and healthier diet, and it may prevent inequity in the dietary intake of children. However, despite consuming school lunches, inappropriate intakes of fat (29.9-47.7\%), dietary fibre (18.1-76.1\%), and salt (97-100\%) were observed for nonnegligible proportions of Japanese schoolchildren ${ }^{(8)}$. These results suggest that the dietary quality consumed either at home or in the out-of-home environment (except school) may be inappropriate considering CVD risk factors, albeit that the traditional Japanese meal is known as the healthier diet having the characteristics of small portion, low energy and low fat ${ }^{(10)}$.

Eating out has been considered a possible factor associated with such inappropriate nutrient intake. In prior reports from Western countries, the characteristic of meals offered to children at restaurants (i.e. kids' meals) was the 
high energy, fat and sodium contents ${ }^{(11-16)}$. Also, meals offered at table-service restaurants included more fruits and vegetables but had larger portion size than those at quick-service restaurants ${ }^{(14,17)}$. In fact, nutrient intake on the days of fast-food consumption was associated with high intakes of energy, fat, sugar and sodium and low intakes of dietary fibre and vitamins ${ }^{(18,19)}$. Eating out has been a common dietary habit among the Japanese population. In prior reports among Japanese children, 19-36\% of them ate out one or more times per week ${ }^{(20,21)}$. This percentage is similar the UK's report that $19 \cdot 0 \%$ of children aged 1.5-18 years ate out one or more times per week $^{(22)}$. For overcoming inappropriate nutrient intake among Japanese children, clarification of the impact of consuming restaurant-served kids' meals is strongly required. However, to date, no studies have shown the impact of kids' meals on nutrient intake among Japanese children. Moreover, little is known about whether the nutritional quality of kids' meals in Japan is inappropriate, like those in Western countries ${ }^{(11-16,18,19)}$.

The present study described the characteristics of kids' meals offered at restaurants commonly available in Japan and analysed the relationship between those characteristics and the fat and salt contents. The nutritional quality assessment of kids' meals may provide useful evidence in future research on the impact of kids' meals on the nutritional intake of Japanese children.

\section{Methods}

\section{Selection of restaurants}

Based on the annual sales in 2016 reported in two publications $^{(23,24)}$, the major companies that operated chain restaurant brand(s) (i.e. fast-food, quick-serve or tableservice restaurants) in Japan and which were ranked within the top ten in each restaurant style listed were identified. In this initial search operation, a total of 212 restaurants from twenty-six companies were identified.

\section{Data collection}

Data were collected from the websites of the subject companies and operated chain restaurant brands in the study period of October to November 2017.

Briefly, the restaurants were first categorized by their styles and types. Three major styles were thereby identified and defined as 'Western-style' (e.g. Western-origin chain restaurants, steak restaurants, burger shops and Italian restaurants), 'Japanese-style' (i.e. chain restaurants offering Japanese-style meals and Asian-origin meals customized in accordance with the preference of Japanese children) and 'mixed-style' (i.e. restaurants offering both Japanese- and Western-style meals). Two types of restaurants were majorly identified and defined as 'fast food' (i.e. those offering self/quick service) and 'table service' (i.e. those offering waiter/table service).

Second, the kids' meals offered in each restaurant were identified. In general, the standard preparation of the kids' meal described on the website was considered as a single portion. If the main dishes, side dishes, soft drinks/beverages and desserts were selectable from multiple choices and their nutrient data were available, all possible combinations were assessed as separate menu items. Otherwise, the assessment of kids' meals was performed in accordance with the descriptions and nutrient data detailed on the website. The choices for sauce/dressing for the main/side dishes and add-ons/toppings were not considered in the nutritional data. Similarly, free refills of bread, salad or soft drinks/beverages were not considered in the nutritional data, because one portion size of these items could not be defined from the information available on the website.

The characteristics of the kids' meals such as price, meal type, sides, incentives and health claim were mainly extracted. The meal type consisted of eight types as follows: 'noodle with soup', 'curry and rice', 'rice-based', 'fish-based', 'meat-based', 'burger/sandwich', 'pasta-based' and 'pancake'. Also, each kids' meal was checked to determine whether the menu included a side dish consisting of vegetables or fries (see online supplementary material, Supplemental Table 1). Since incentives likely increase the frequency of kids' meal consumption as well as develop an unhealthy eating pattern contributing to child obesity ${ }^{(25,26)}$, whether the kids' meal was offered with a free soft drink/beverage, dessert or toy was checked. In addition, whether the kids' meal was offered with a health claim (e.g. 'low energy', 'low fat', 'low sodium') was also identified.

Nutritional data were also excerpted from companies' and restaurants' websites. A restaurant-defined single portion of each kids' meal was subjected to assessment. All nutrients reported on the website for each kids' meal were basically excerpted, but inquiries via email/telephone were made when the details on energy $(\mathrm{kJ})$, protein $(\mathrm{g})$, fat $(\mathrm{g})$, carbohydrate $(\mathrm{g})$ or salt $(\mathrm{g})$ content of the dishes were not reported on the website. The latest information about energy-providing nutrients (such as protein, fat and carbohydrate) reported in response to the inquiries were used for calculation of energy values by adaptation of general coefficients (i.e. $16 \cdot 7,37 \cdot 7$ and $16 \cdot 7 \mathrm{~kJ}$ per $1 \mathrm{~g}$ for protein, fat and carbohydrate, respectively) rather than using the information reported on the website. Information regarding the fat content, SFA and trans-fatty acids was also excerpted, whenever possible. When only sodium content (mg) was reported instead of salt content (g), the salt equivalent value was calculated by using the following formula: salt $(\mathrm{g})=2.54 \times \operatorname{sodium}(\mathrm{mg}) / 1000$.

Before the analysis, for the selection of kids' meals that are widely available in Japan, chain restaurants that met the following criteria were excluded from the first 
212 chain restaurants identified: restaurants with fewer than three outlets ( $n$ 49) and those with outlets located in fewer than five of all forty-seven prefectures ( $n$ 21). In addition, buffet restaurants, coffee shops, bakery shops, convenience food shops and bars were excluded ( $n$ 56). Restaurants that neither offered kids' meals ( $n$ 27) nor reported nutritional data for menu items ( $n$ 17) were also excluded.

Finally, 438 kids' meals offered by forty-two chain restaurant brands from across twenty food-service companies were assessed in the present study.

\section{Statistical analysis}

Descriptive statistics for the characteristics of kids' meals by restaurant style were first calculated. For assessment of the nutritional adequacy of each kids' meal, the nutrient regulation imposed by the Gakkou Kyushoku Jissi Kijyun (Standards for the SLP) was used as a standard reference $^{(9)}$. The SLP indicated standard nutrient contents of meals offered as school lunches for four different age categories of children (6-7, 8-9, 10-11 and $12-14$ years). For the energy content, the SLP standard values for the lowest age category (6-7 years: $2218 \mathrm{~kJ}(530 \mathrm{kcal}))$ and highest age category (12-14 years: $3431 \mathrm{~kJ}$ ( $820 \mathrm{kcal})$ ) were used for comparison. Kids' meals whose energy content exceeded the respective SLP's standard value were considered to be inappropriate. The protein content was assessed similarly. The SLP's standard for the protein content at $20 \mathrm{~g}$ for the age group 6-7 years and $30 \mathrm{~g}$ for the age group 12-14 years was used for assessment. The percentage of energy from fat (fat $\mathrm{E} \%$ ) was calculated for each kids' meal, and the kids' meal was considered inappropriate in its fat content if the fat $\mathrm{E} \%$ exceeded the upper limit (30\%) of the SLP regulation (range: $25-30 \%$ ). For salt content, the SLP's standard at $<2 \mathrm{~g}$ for the age group 6-7 years and $<3 \mathrm{~g}$ for the age group 12-14 years was used for assessment. Thus, the salt content equal to or more than those standards was considered inappropriate.

In the next step, two separate linear mixed models were used for the evaluation of the association between the characteristics of kids' meals and the fat $\mathrm{E} \%$ or salt content. It was speculated that the nutritional data of kids' meals were correlated to each other within the restaurant because more than one kids' meal was offered at every restaurant. Therefore, as Model 0 , the random intercepts for the company level and restaurant level were first included in the model to test and adjust for the potential correlation among kids' meal data. If the correlation was observed, significant company- and restaurant-level variance would be observed. The model could include and adjust for these variances in the further analysis regarding the relationship between kids' meal characteristics and the nutrient contents.

The nutrient content of kids' meals might be associated with the type of kids' meal. On the other hand, the relationship between the nutrient contents and the type of meal might be confounded by other characteristics such as the inclusion of sides and incentives. Thus, Model 1 included price, energy (if adequate) and the type of kids' meal. Then Model 2 additionally included sides (fries or vegetables) and incentives (sugar-sweetened beverage, dessert or toy) to assess the confounding. If significant restaurant-level variance was still observed in the result of Model 2, the nutrient contents of kids' meals might be influenced by restaurant-level characteristics. Hence, the effect of the type and the style of the restaurant were assessed in Model 3. At the same time, Model 3 would be able to show what percentage of the restaurant-level variance was explained by the difference in the style and type of restaurants. These results may be useful to discuss the contextual effects derived from the style or type of restaurant on the nutrient contents of kids' meals ${ }^{(27)}$.

All statistical analyses were conducted with the statistical software package SAS version 9.4 and $P<0.05$ was considered statistically significant.

\section{Results}

The mean energy in 438 kids' meals was 2113 (sD 657) kJ (505 (SD 157) kcal), and this trend was consistent across different restaurant styles. 'Burger/sandwich' (29.0\%) and 'meat-based' $(27.6 \%)$ were the most common types of kids' meal served. As a side dish, $59.4 \%$ of the kids' meals contained fries, while $35.5 \%$ of them contained vegetables. More than $50 \%$ of kids' meals were offered with an incentive such as a sugar-sweetened beverage (71.7\%), dessert $(51.4 \%)$ or toy (63.0\%; Table 1$)$. Only three brands reported the portion size (weight) of the kids' meal and none reported regarding the presence of saturated or trans-fatty acids on their websites.

About $60 \%$ of kids' meals met the energy content of $\leq 2218 \mathrm{~kJ}$ and almost all meals met that of $\leq 3431 \mathrm{~kJ}$ (Table 2). Also, $40.6 \%$ of the kids' meals had appropriate fat $\mathrm{E} \%$, and 34.5 and $71.5 \%$ of kids' meals had salt content of $<2$ and $<3 \mathrm{~g}$, respectively. Regarding protein, $15.8 \%$ of kids' meals met the protein content of $\geq 20 \mathrm{~g}$ but only $1.6 \%$ of kids' meals met that of $\geq 30 \mathrm{~g}$ (Table 2). Finally, $15.5 \%$ ( $n$ 68) of the kids' meals met the multiple SLP standard values for energy, fat and salt contents (Table 2). In the assessment based on meal style, lower percentage of appropriate fat $\mathrm{E} \%$ was observed for 'meat-based' meals (19.8\%) and 'burger/sandwich' (24.4\%; Table 3). Lower percentages of appropriate salt content were observed for 'noodle with soup' (12.5\%), 'rice-based' meals (23.8\%), 'fish-based' meals (13.0\%) and 'burger/sandwich' (1.6\%; Table 3). Also, the most appropriate meals regarding protein content were the 'meat-based' (33.9\%) and 'fishbased' (43.5\%) kids' meals (Table 3 ).

Since significant restaurant-level variance was observed in fat $\mathrm{E} \%(21.7, P<0.05)$ and salt content $(1.3, P<0.05)$, 
Table 1 Characteristics of meals offered to children (kids' meals) at chain restaurants in Japan, overall and by restaurant style, OctoberNovember 2017

\begin{tabular}{|c|c|c|c|c|c|c|c|c|}
\hline & \multirow{2}{*}{\multicolumn{2}{|c|}{$\begin{array}{l}\text { All kids' meals } \\
\quad(n \text { 438) }\end{array}$}} & \multicolumn{6}{|c|}{ Kids' meals by restaurant style } \\
\hline & & & \multicolumn{2}{|c|}{$\begin{array}{c}\text { Japanese-style restaurant } \\
(n \text { 117) }\end{array}$} & \multicolumn{2}{|c|}{$\begin{array}{l}\text { Western-style restaurant } \\
\text { ( } n \text { 271) }\end{array}$} & \multicolumn{2}{|c|}{$\begin{array}{l}\text { Mixed-style restaurant } \\
\qquad(n 50)\end{array}$} \\
\hline & Mean or $n$ & SD or $\%$ & Mean or $n$ & SD or $\%$ & Mean or $n$ & SD or $\%$ & Mean or $n$ & SD or $\%$ \\
\hline \multicolumn{5}{|l|}{ Nutritional data } & $4 \cdot 47$ & $0 \cdot 80$ & 4.43 & 1.41 \\
\hline Energy (kJ) & 2113 & 657 & 2151 & 669 & 2105 & 623 & 2067 & 778 \\
\hline Energy (kcal) & 505 & 157 & 514 & 160 & 503 & 149 & 494 & 186 \\
\hline Protein $(\mathrm{g})$ & $15 \cdot 3$ & $6 \cdot 3$ & $14 \cdot 8$ & $7 \cdot 2$ & 15.4 & 5.5 & $16 \cdot 1$ & 8.2 \\
\hline Protein (E\%) & $12 \cdot 2$ & 4.0 & 11.5 & $3 \cdot 7$ & $12 \cdot 4$ & 4.2 & $12 \cdot 3$ & 3.8 \\
\hline Fat $(\mathrm{g})$ & $20 \cdot 3$ & $10 \cdot 4$ & $16 \cdot 5$ & $5 \cdot 7$ & $22 \cdot 0$ & 11.0 & $19 \cdot 2$ & $12 \cdot 2$ \\
\hline Fat (E\%) & 34.5 & 11.3 & $29 \cdot 0$ & 7.6 & $37 \cdot 3$ & 11.4 & 31.4 & $12 \cdot 8$ \\
\hline Carbohydrates (g) & $67 \cdot 6$ & $20 \cdot 7$ & $75 \cdot 9$ & 25.4 & 64.5 & $17 \cdot 8$ & $65 \cdot 9$ & $19 \cdot 3$ \\
\hline Carbohydrates (E\%) & $54 \cdot 3$ & $12 \cdot 8$ & $59 \cdot 3$ & 8.7 & $52 \cdot 1$ & 13.4 & $55 \cdot 3$ & $14 \cdot 3$ \\
\hline Salt $(g)$ & $2 \cdot 6$ & 1.4 & 3.7 & $2 \cdot 0$ & $2 \cdot 2$ & 0.8 & 2.4 & $1 \cdot 2$ \\
\hline Salt (g/4184 kJ (1000 kcal)) & 5.4 & $3 \cdot 1$ & $7 \cdot 3$ & $3 \cdot 7$ & 4.6 & 1.8 & $5 \cdot 7$ & 4.8 \\
\hline \multicolumn{9}{|l|}{ Type of meal } \\
\hline Noodle with soup & 48 & $11 \cdot 0$ & 37 & $31 \cdot 6$ & 3 & $1 \cdot 1$ & 8 & $16 \cdot 0$ \\
\hline Curry and rice & 40 & $9 \cdot 1$ & 20 & $17 \cdot 1$ & 13 & 4.8 & 7 & $14 \cdot 0$ \\
\hline Rice-based & 21 & $4 \cdot 8$ & 17 & 14.5 & 1 & 0.4 & 3 & $6 \cdot 0$ \\
\hline Fish-based & 23 & $5 \cdot 3$ & 20 & $17 \cdot 1$ & 0 & 0.0 & 3 & $6 \cdot 0$ \\
\hline Meat-based & 121 & 27.6 & 20 & $17 \cdot 1$ & 82 & $30 \cdot 3$ & 19 & 38.0 \\
\hline Burger/sandwich & 127 & $29 \cdot 0$ & 0 & 0.0 & 127 & $46 \cdot 9$ & 0 & 0.0 \\
\hline Pasta-based & 18 & 4.1 & 0 & 0.0 & 14 & $5 \cdot 2$ & 4 & 8.0 \\
\hline Pancake & 40 & $9 \cdot 1$ & 3 & $2 \cdot 6$ & 31 & 11.4 & 6 & $12 \cdot 0$ \\
\hline \multicolumn{9}{|l|}{ Side dish§ } \\
\hline Vegetables & 157 & $35 \cdot 8$ & 30 & $25 \cdot 6$ & 101 & $37 \cdot 3$ & 26 & $52 \cdot 0$ \\
\hline Fries & 260 & 59.4 & 57 & 48.7 & 181 & $66 \cdot 8$ & 22 & $44 \cdot 0$ \\
\hline \multicolumn{9}{|l|}{ Incentive || } \\
\hline Sugar-sweetened beverage & 314 & $71 \cdot 7$ & 84 & $71 \cdot 8$ & 211 & 77.9 & 19 & 38.0 \\
\hline Dessert & 225 & $51 \cdot 4$ & 81 & 69.2 & 104 & 38.4 & 40 & $80 \cdot 0$ \\
\hline Toy & 276 & 63.0 & 73 & $62 \cdot 4$ & 184 & 67.9 & 19 & 38.0 \\
\hline \multicolumn{9}{|l|}{ Health claim } \\
\hline Yes & 30 & 6.9 & 4 & 3.4 & 17 & $6 \cdot 3$ & 9 & $18 \cdot 0$ \\
\hline No & 408 & $93 \cdot 2$ & 113 & $96 \cdot 6$ & 254 & $93 \cdot 7$ & 41 & $82 \cdot 0$ \\
\hline \multicolumn{9}{|l|}{ Type of restaurant } \\
\hline Fast food/quick service & 250 & $57 \cdot 1$ & 54 & $46 \cdot 2$ & 196 & $72 \cdot 3$ & 0 & 0.0 \\
\hline Table service & 188 & $42 \cdot 9$ & 63 & $53 \cdot 9$ & 75 & $27 \cdot 7$ & 50 & $100 \cdot 0$ \\
\hline
\end{tabular}

E\%, percentage of energy.

Kids' meals from forty-two chain restaurant brands from across twenty food-service companies were assessed. Continuous variables are presented as mean and SD; categorical variables are presented as $n$ and \%.

$\ddagger$ WUS $1=¥ J P 110$.

$\S$ The number of kids' meals that were offered with a side dish, including vegetables or fries.

I|The number of kids' meals that were offered with a sugar-sweetened beverage, dessert or toy incentive.

ףHealth claims (e.g. 'low energy', 'low fat' or 'low salt') provided in the description of the kids' meal in the companies' or brands' websites.

further analysis still used the linear mixed model (Table 4). Compared with 'burger/sandwich', fat E\% was higher in 'meat-based' meals but lower in 'curry and rice', 'fishbased' meals and 'pancake'. Also, salt content was higher in 'noodle with soup' and 'fish-based' meals but lower in 'meat-based' meals and 'pancake' (Table 4). Inclusion of sides and incentives in the model did not alter these relationships. The inclusion of fries as a side dish was significantly associated with an increase in fat $\mathrm{E} \%(\beta=8.8$; $95 \%$ CI $6 \cdot 6,11.0)$ but associated with a decrease in salt content $(\beta=-0 \cdot 5 ; 95 \% \mathrm{CI}-0 \cdot 8,-0 \cdot 2$; Table 4$)$. In addition, the 'Japanese-style' (restaurant-level characteristic) was significantly associated with a decrease in fat $\mathrm{E} \%$ $(\beta=-6 \cdot 2 ; 95 \%$ CI $-11 \cdot 0,-1 \cdot 4)$ but associated with an increase in salt content $(\beta=0.7 ; 95 \%$ CI $0.06,1 \cdot 3)$. At the same time, $39 \%$ of the restaurant-level variance of fat $\mathrm{E} \%$ was explained by the type and style of restaurant (Model $2,24 \% v$. Model 3, 63\%). Sixty-nine per cent of restaurantlevel variance was explained by the kids' meal characteristic regarding salt content. An additional 8\% was explained by the type and style of restaurant regarding salt content (Model 2, 69\% v. Model 3, 77\%; Table 4).

\section{Discussion}

The present study aimed at assessing the nutritional quality of kids' meals offered at Japanese chain restaurants. More than half of the kids' meals being served in the subject restaurants had inappropriate fat and salt contents, with reference to the SLP. The inappropriateness varied across different types of kids' meal and different styles of 
Table 2 Percentage of meals offered to children (kids' meals) at chain restaurants in Japan meeting the Standard for the School Lunch Program (SLP), overall and by restaurant style, October-November 2017

\begin{tabular}{l} 
All kids' meals \\
\cline { 5 - 7 }
\end{tabular}

restaurant. Overall, the kids' meals offered at Japanese-style restaurants were low in fat content, but high in salt content, as compared with meals offered at Western-style restaurants. In addition, the availability of nutritional information, such as the SFA content, the portion size and any health claims, was limited. These results suggest that the nutrient contents of kids' meals in Japan can be improved in lieu of the fact that the high availability of kids' meals in most restaurants may pose a health risk through inappropriate fat and salt intakes among Japanese children.

The kids' meals in Japanese-style restaurants had low fat content but high salt content compared with those served in Western-style restaurants (Tables 4). The cause of the low fat content of Japanese kids' meals may be the low usage of meat. A recent study suggested that the main sources of SFA intake among Japanese children are meat, dairy products and confectioneries ${ }^{(28)}$. Thus, a kids' meal which contains less meat or fewer dairy products is considered a low-fat meal. Compared with the Western-style restaurants, 'noodle with soup', 'rice-based' meal and 'fishbased' meal were commonly offered at the Japanese-style restaurants (Table 1 ). These meals are consisting mainly of staple foods and fish. In these meals, energy from carbohydrate and protein may account for large percentages compared with the contribution from fat. In contrast, the types of kids' meal commonly offered at Western-style restaurants were 'meat-based' meal and 'burger/sandwich'. These meals including meat had higher fat E\% than the other types of meal (Tables 3 and 4).

Such difference in the fat content of kids' meals by restaurant style might be derived from the difference in dietary characteristics of Western and East Asian countries ${ }^{(29)}$. Gabriel et al. mentioned that the traditional Japanese diet is offered with the combination of cooked rice, soup, main and sides ${ }^{(10)}$. The relatively small portion size of main and side dishes including fish and vegetables is also mentioned as a characteristic of the traditional Japanese diet ${ }^{(10)}$. These characteristics may be associated with low usage of meat and the low fat content of the Japanese-style kids' meal.

However, on the other hand, characteristics of the traditional Japanese diet may also link with the high salt content of the Japanese-style kids' meal. Asakura et al. reported that dietary salt consumed from seasonings, fish and noodles accounts for more than $70 \%$ of the habitual salt intake in the Japanese population ${ }^{(30)}$. The source of salt intake in Japan represents quite a difference from Western countries whose main source of salt intake is breads $^{(31)}$. The traditional Japanese diet commonly includes soup cooked with several seasonings such as soya source, miso and soup stock ${ }^{(10)}$. Also, noodles are generally served in a hot soup or with a dipping sauce. Thus, the meal including noodles or soup tends to contain much salt. Since almost all kids' meals categorized into 'noodle with soup' and 'fish-based' meal were from the Japanese-style restaurants, the salt content of the kids' meals might be higher in the Japanese-style restaurant compared with the Western-style restaurants (Table 4). As a population approach, chain restaurants should reduce the salt content in kids' meals in all outlets across Japan at the same time. Also, a gradual reduction of salt would not reduce customer satisfaction ${ }^{(32)}$. 
Table 3 Nutritional data and percentage of meals offered to children (kids' meals) at chain restaurants in Japan meeting the Standard for the School Lunch Program (SLP), by meal type, October-November 2017

\begin{tabular}{|c|c|c|c|c|c|c|c|c|c|c|c|c|c|c|c|c|}
\hline & \multicolumn{16}{|c|}{ Kids' meals by meal type } \\
\hline & \multicolumn{2}{|c|}{$\begin{array}{c}\text { Noodle with soup } \\
\text { (n 48) }\end{array}$} & \multicolumn{2}{|c|}{$\begin{array}{c}\text { Curry and rice } \\
(n \text { 40) }\end{array}$} & \multicolumn{2}{|c|}{$\begin{array}{c}\text { Rice-based } \\
\left(\begin{array}{l}n \text { 21) } \\
\end{array}\right.\end{array}$} & \multicolumn{2}{|c|}{$\begin{array}{c}\text { Fish-based } \\
(n \text { 23) }\end{array}$} & \multicolumn{2}{|c|}{$\begin{array}{c}\text { Meat-based } \\
(n 121)\end{array}$} & \multicolumn{2}{|c|}{$\begin{array}{c}\text { Burger/sandwich } \\
(n \text { 127) }\end{array}$} & \multicolumn{2}{|c|}{$\begin{array}{c}\text { Pasta-based } \\
(n \text { 18) } \\
\end{array}$} & \multicolumn{2}{|c|}{$\begin{array}{c}\text { Pancake } \\
(n \text { 40) } \\
\end{array}$} \\
\hline & Mean or $n$ & SD or $\%$ & Mean or $n$ & SD or $\%$ & Mean or $n$ & SD or $\%$ & Mean or $n$ & SD or $\%$ & Mean or $n$ & SD or $\%$ & Mean or $n$ & SD or $\%$ & Mean or $n$ & SD or $\%$ & Mean or $n$ & SD or $\%$ \\
\hline \multicolumn{17}{|l|}{ Energył } \\
\hline $\mathrm{kJ}$ & 1682 & 548 & 1845 & 636 & 2464 & 343 & 2351 & 657 & 2377 & 669 & 2255 & 519 & 1695 & 435 & 1523 & 544 \\
\hline kcal & 402 & 131 & 441 & 152 & 589 & 82 & 562 & 157 & 568 & 160 & 539 & 124 & 405 & 104 & 364 & 130 \\
\hline$\leq 2218 \mathrm{~kJ}(530 \mathrm{kcal})$ & 44 & 91.7 & 27 & 67.5 & 11 & 52.4 & 11 & $47 \cdot 8$ & 56 & $46 \cdot 3$ & 61 & 48.0 & 15 & $83 \cdot 3$ & 38 & $95 \cdot 0$ \\
\hline$\leq 3431 \mathrm{~kJ}(820 \mathrm{kcal})$ & 48 & $100 \cdot 0$ & 40 & $100 \cdot 0$ & 20 & $95 \cdot 2$ & 21 & 91.3 & 116 & 95.9 & 127 & $100 \cdot 0$ & 18 & $100 \cdot 0$ & 40 & $100 \cdot 0$ \\
\hline \multicolumn{17}{|l|}{ Protein } \\
\hline g & $12 \cdot 2$ & $4 \cdot 4$ & $9 \cdot 8$ & $4 \cdot 8$ & $12 \cdot 6$ & $5 \cdot 5$ & $20 \cdot 7$ & 3.5 & $20 \cdot 0$ & $6 \cdot 1$ & $16 \cdot 0$ & 3.5 & $11 \cdot 1$ & 4.0 & $7 \cdot 3$ & $4 \cdot 1$ \\
\hline$\geq 20 \mathrm{~g}$ & 2 & $4 \cdot 2$ & 1 & $2 \cdot 5$ & 2 & 9.5 & 10 & 43.5 & 41 & 33.9 & 11 & $8 \cdot 7$ & 1 & $5 \cdot 6$ & 1 & 2.5 \\
\hline$\geq 30 \mathrm{~g}$ & 0 & 0.0 & 0 & 0.0 & 0 & 0.0 & 0 & 0.0 & 7 & $5 \cdot 8$ & 0 & 0.0 & 0 & 0.0 & 0 & 0.0 \\
\hline \multicolumn{17}{|l|}{ Fat§ } \\
\hline$E \%$ & $29 \cdot 7$ & $11 \cdot 3$ & $24 \cdot 1$ & 8.0 & $32 \cdot 3$ & $9 \cdot 1$ & 23.3 & $7 \cdot 2$ & $42 \cdot 8$ & 11.4 & 35.4 & 6.9 & $35 \cdot 6$ & $10 \cdot 3$ & $26 \cdot 9$ & $9 \cdot 2$ \\
\hline$\leq 30.0 \mathrm{E} \%$ & 25 & $52 \cdot 1$ & 33 & 82.5 & 14 & $66 \cdot 7$ & 20 & $87 \cdot 0$ & 24 & $19 \cdot 8$ & 31 & $24 \cdot 4$ & 8 & $44 \cdot 4$ & 23 & $57 \cdot 5$ \\
\hline \multicolumn{17}{|l|}{ Saltt } \\
\hline g & 4.4 & $1 \cdot 7$ & $2 \cdot 3$ & 1.5 & $2 \cdot 6$ & 0.6 & $4 \cdot 4$ & $2 \cdot 2$ & $2 \cdot 3$ & $1 \cdot 1$ & $2 \cdot 7$ & 0.5 & 1.9 & 0.7 & $1 \cdot 0$ & 0.5 \\
\hline$<2 \mathrm{~g}$ & 6 & $12 \cdot 5$ & 24 & $60 \cdot 0$ & 5 & 23.8 & 3 & $13 \cdot 0$ & 61 & $50 \cdot 4$ & 2 & $1 \cdot 6$ & 11 & $61 \cdot 1$ & 39 & 97.5 \\
\hline$<3 \mathrm{~g}$ & 10 & $20 \cdot 8$ & 34 & 85.0 & 18 & $85 \cdot 7$ & 8 & $34 \cdot 8$ & 94 & $77 \cdot 7$ & 94 & 74.2 & 16 & 88.9 & 39 & 97.5 \\
\hline \multicolumn{17}{|l|}{ Multiple SLP || } \\
\hline Fat and salt & 6 & $12 \cdot 5$ & 22 & $55 \cdot 0$ & 4 & $19 \cdot 1$ & 2 & $8 \cdot 7$ & 10 & $8 \cdot 3$ & 2 & 1.6 & 6 & 33.3 & 23 & 57.5 \\
\hline Fat, salt and energy & 6 & $12 \cdot 5$ & 20 & $50 \cdot 0$ & 3 & $14 \cdot 3$ & 1 & $4 \cdot 3$ & 10 & $8 \cdot 3$ & 2 & 1.6 & 4 & $22 \cdot 2$ & 22 & $55 \cdot 0$ \\
\hline
\end{tabular}

E\%, percentage of energy. Kids' meals from forty-two chain restaurant brands from across twenty food-service compants
as $n$ and \%. †The SLP was used for adequacy assessment of energy, protein and salt contents per one
(12-14 years: $\leq 3431 \mathrm{~kJ}$ ( $820 \mathrm{kcal}), \geq 30 \mathrm{~g}$ of protein and $<3 \mathrm{~g}$ of salt content).

SThe SLP was used for fat content per one meal ( $\leq 30 \mathrm{E} \%$ from fat for all age categories).

The percentage of kids' meals meeting multiple standards of the SLP. The standard for energy and salt content was used for the lowest age category (6-7 years: $\leq 2218 \mathrm{~kJ}$ and $<2 \mathrm{~g}$ of salt content). 
Table 4 Association of meal and restaurant characteristics with percentage of energy from fat and salt content of meals offered to children (kids' meals) at chain restaurants in Japan, OctoberNovember 2017

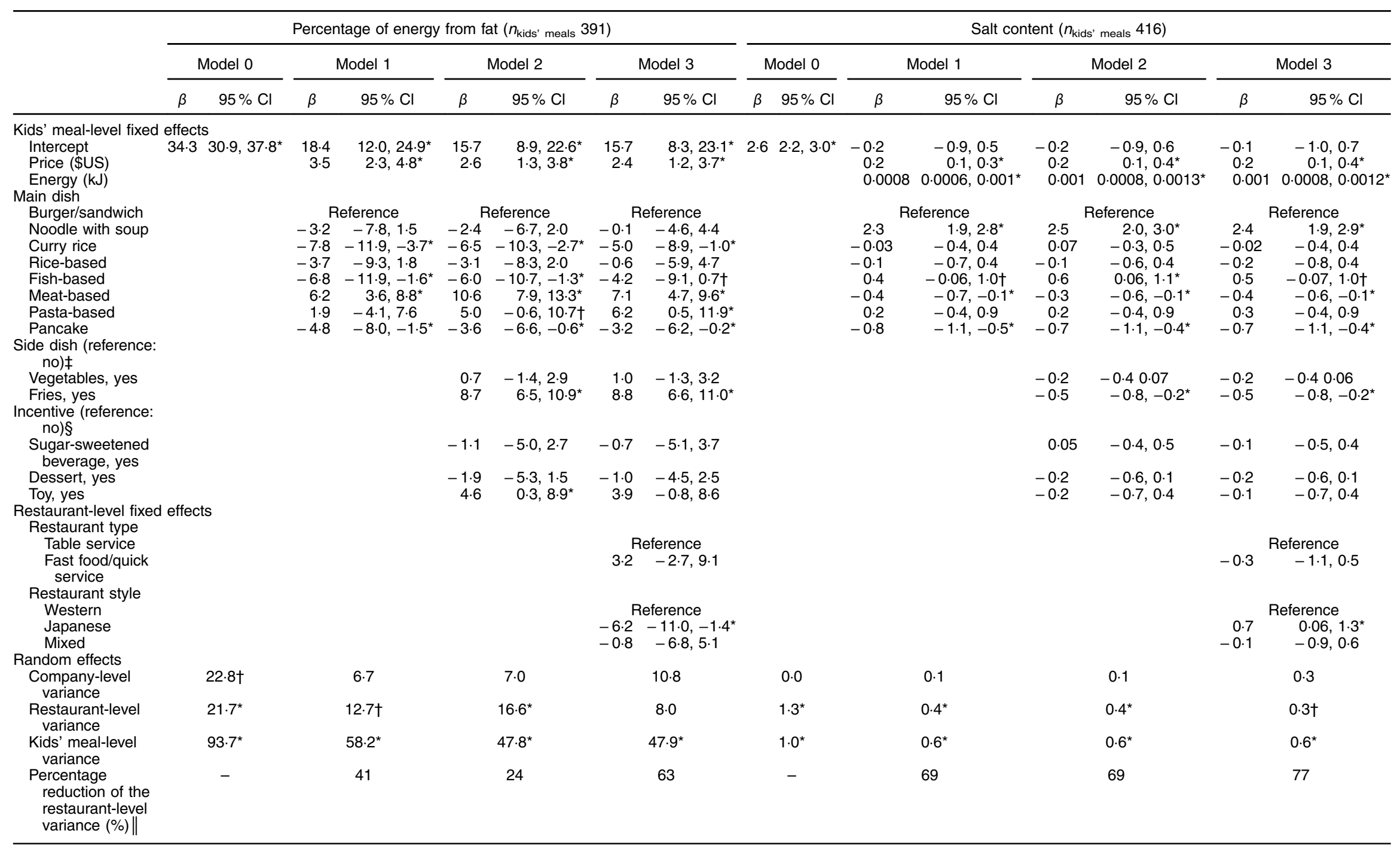

Kids' meals from forty-two chain restaurant brands from across twenty food-service companies were assessed.

*Statistically significant based on $95 \% \mathrm{Cl}(P<0.05)$.

†Marginal association based on $95 \% \mathrm{Cl}(P<0.10)$.

KKids' meals offered with a side dish, including vegetables or fries.

SKids' meals offered with a sugar-sweetened beverage, dessert or toy incentive.

$\|$ Percentage reduction of the restaurant-level variance from Model 0 . 
The difference in nutrient contents between kids' meals offered at Japanese-style and Western-style restaurants was well presented in the statistical model of the current study. The Japanese restaurant style was significantly associated with low fat $\mathrm{E} \%$ and high salt content of the kids' meals (Table 4). At the same time, the difference in restaurant style explained approximately 40 and $8 \%$ of between-restaurant variations in fat $\mathrm{E} \%$ and salt content of the kids' meals, respectively. These results suggest that the kids' meals offered at the Japanese-style restaurants were potentially influenced by the characteristics of the traditional Japanese-style diet. Also, they suggest that the inappropriate fat $\mathrm{E} \%$ and high salt content were derived from different cultural contexts of the Western and the Japanese diet.

The protein content of kids' meals should be improved in addition to the fat $\mathrm{E} \%$ and salt contents. Only $15 \cdot 8 \%$ of kids' meals met the $\geq 20 \mathrm{~g}$ of protein content regulated by the SLP. However, most of the kids' meals meeting the SLP for protein content were 'meat-based' meals and 'burger/ sandwich', which were inappropriate regarding high fat E\% (Table 3). Positive consideration is needed about the use of lean meat or more plant-based protein in kids' meals while considering the appropriateness of fat $\mathrm{E} \%$. To date, a nationwide study has shown that schoolchildren consume a sufficient amount of protein ${ }^{(8)}$. Careful monitoring of the relationship between the frequency of eating out and insufficient protein intake is also needed to ensure the adequate and optimal dietary intake for the progressive growth of Japanese children.

Much room for improvement was recognized with respect to the availability of nutritional information about kids' meals in Japan. Almost all restaurants did not report the meal's portion size (or weight of the meal) on their websites. Large portion size and high energy density (i.e. the energy content per unit weight of food) may affect weight gain ${ }^{(3-5)}$. Moreover, children are likely to underestimate their energy consumption in the restaurant setting ${ }^{(33)}$. The lack of information on portion size may make it difficult for a consumer to select a healthier food, as well as affect the detailed dietary assessment by food record, food recall and FFQ. Although children's SFA intake exceeds the tentative dietary goal for adults $(<7 \mathrm{E} \%)$ in Japan and the major SFA source is meat and dairy products $^{(28)}$, none of the restaurants reported the SFA content of kids' meals on their websites, although 'meat-based' meal was the major type of kids' meal identified. On the contrary, a kids' meal, which is high in fat $\mathrm{E} \%$, was likely to be offered with a free toy incentive (Table 4), indicating that children are likely to have such meals more, which may increase their SFA consumption ${ }^{(26)}$. The relationship between the inclusion of a toy and fat E\% was not statistically significant in Model 3 (Table 4). Since the significant relationship was observed in Model 2, the statistical power to detect the association might be reduced due to the inclusion of additional variables. The point estimate and its direction suggested that kids' meals high in fat E\% were offered with toys. Several measures such as the establishment of nutritional criteria $^{(34)}$, menu labelling ${ }^{(35,36)}$ and toy ordinance ${ }^{(34)}$ may contribute to healthier food choices at eateries. Further research is needed to assess whether these measures can contribute significantly to achieving appropriate nutrient intake among Japanese children.

The results of the present study are consistent with reports from Western countries. The energy and fat contents of kids' meals in Japan were comparable to or slightly lower than those reported for restaurants in Western countries. The mean energy content of kids' meals offered at restaurants was $1883-3347 \mathrm{~kJ}(450-800 \mathrm{kcal})$ in the USA and Canada ${ }^{(11-13,15,16)}$. These are slightly higher than the present study, which reported the mean energy content of kids' meals as 2113 (sD 657) kJ (505 (sD 157) kcal; Table 1). The mean fat content of kids' meals was 17.4-33 g in Western countries ${ }^{(11-16)}$, which is slightly higher than or comparable to $20.3 \mathrm{~g}$ in Japan (Table 1). The mean salt content of kids' meals served at Japanese-style restaurants was $3.7 \mathrm{~g}$, which is higher compared with $1 \cdot 3-3.2 \mathrm{~g}$ of mean salt content in the kids' meals of Western countries $^{(11-16)}$. Cumulatively, the nutrient contents of the kids' meals in Japan may be characterized by at least two different cultural contexts which have different shortcomings regarding CVD risk factors. For the establishment of regulation on the nutrient contents of kids' meals in Japan, a careful consideration based on the understanding of Western and Japanese dietary cultural contexts will be needed.

To the best of the author's knowledge, the present study is the first to assess the nutritional quality of kids' meals offered in Japan across an assortment of restaurants with Western and Asian cultural characteristics. In addition, kids' meals were extracted from restaurants that were widely distributed across Japan to ensure the inclusion of kids' meals that were consumed by the majority of Japanese children.

The present study has several limitations. First, the low comprehensiveness of a typical kids' meal may have induced bias in data interpretation. Only those kids' meals whose nutritional information was available on the restaurants' websites were assessed, while takeaway meals were not included in the present study. A more rigorous study needs to be performed on a large variety of kids' meals that are consumed away from home and which may contribute to health risk due to inappropriate nutrient intake among Japanese children. Second, an arbitrary grouping of kids' meals may have caused misclassification, which affects comparability with past reports. In fact, an international collaboration to track the nutrition composition of fast foods has proposed a categorization system ${ }^{(37)}$. However, in Japan, the majority of kids' meals offered at Japanese-style restaurants could only be categorized as 'Asian-other' group by this system. Therefore, the present study used an original categorization system for more 
detailed assessment of kids' meals in Japan. Third, only a limited number of nutrients were assessed in the present study. While the SLP regulates several other nutrients such as iron, calcium and vitamins, only the contents of macronutrients and salt were assessed in the current study because of the low availability of nutrient information on the respective restaurants' websites. However, the inappropriateness of macronutrient and salt intakes was identified as a priority regarding public health issues among Japanese children ${ }^{(8,28)}$. Finally, the situation of kids' meals in Japan revealed by the present study could be tentative under the possibility of replacement or modification of kids' meals by each of the assessed brands. Thus, the particular basic kids' meal should be used for monitoring of the nutritional quality of kids' meals at restaurants $^{(38-40)}$.

\section{Conclusion}

The characteristics of the restaurant-served kids' meals in Japan were high fat E\% and high salt content. These might be derived from the different dietary cultural contexts of Westerners and the Japanese.

\section{Acknowledgements}

Financial support: This research received no specific grant from any funding agency in the public, commercial or not-for-profit sectors. Conflict of interest: None. Authorship: All processes of the current research were conducted by K.U. Ethics of human subject participation: Not applicable.

\section{Supplementary material}

To view supplementary material for this article, please visit https://doi.org/10.1017/S1368980018001891

\section{References}

1. Abarca-Gómez L, Abdeen ZA, Hamid ZA et al. (2017) Worldwide trends in body-mass index, underweight, overweight, and obesity from 1975 to 2016: a pooled analysis of 2416 population-based measurement studies in 128.9 million children, adolescents, and adults. Lancet 390, 26272642.

2. Ng M, Fleming T, Robinson M et al. (2014) Global, regional, and national prevalence of overweight and obesity in children and adults during 1980-2013: a systematic analysis for the Global Burden of Disease Study 2013. Lancet 384, 766781.

3. Rosenheck R (2008) Fast food consumption and increased caloric intake: a systematic review of a trajectory towards weight gain and obesity risk. Obes Rev 9, 535-547.

4. Stender S, Dyerberg J \& Astrup A (2007) Fast food: unfriendly and unhealthy. Int J Obes (Lond) 31, 887-890.
5. Diliberti N, Bordi PL, Conklin MT et al. (2004) Increased portion size leads to increased energy intake in a restaurant meal. Obesity (Silver Spring) 12, 562-568.

6. Shirasawa $\mathrm{T}$, Ochiai $\mathrm{H}$, Nanri $\mathrm{H}$ et al. (2015) Trends of underweight and overweight/obesity among Japanese schoolchildren from 2003 to 2012, defined by body mass index and percentage overweight cutoffs. J Epidemiol 25, 482-488.

7. Yoshinaga M, Ichiki T, Tanaka Y et al. (2010) Prevalence of childhood obesity from 1978 to 2007 in Japan. Pediatr Int 52, 213-217.

8. Asakura K \& Sasaki S (2017) School lunches in Japan: their contribution to healthier nutrient intake among elementaryschool and junior high-school children. Public Health Nutr 20, 1523-1533.

9. Ministry of Education Culture Sports Science and Technology Japan (2013) Gakkou Kyushoku Jisshi Kijyun (Standards for School Lunch Program). http://www.mext.go.jp/b_menu/ hakusho/nc/_icsFiles/afieldfile/2013/03/21/1332086_1.pdf (accessed March 2018).

10. Gabriel AS, Ninomiya K \& Uneyama H (2018) The role of the Japanese traditional diet in healthy and sustainable dietary patterns around the world. Nutrients 10, E173.

11. Semnani-Azad Z, Scourboutakos MJ \& L'Abbé MR (2016) Kids' meals from Canadian chain restaurants are exceedingly high in calories, fats, and sodium: a cross-sectional study. BMC Nutr 2, 16.

12. Deierlein AL, Peat K \& Claudio L (2015) Comparison of the nutrient content of children's menu items at US restaurant chains, 2010-2014. Nutr J 14, 80.

13. Wu HW \& Sturm R (2013) What's on the menu? A review of the energy and nutritional content of US chain restaurant menus. Public Health Nutr 16, 87-96.

14. Reeves S, Wake Y \& Zick A (2011) Nutrition labeling and portion size information on children's menus in fast-food and table-service chain restaurants in London, UK. $J$ Nutr Educ Behav 43, 543-547.

15. O'Donnell SI, Hoerr SL, Mendoza JA et al. (2008) Nutrient quality of fast food kids' meals. Am J Clin Nutr $\mathbf{8 8}$, $1388-1395$.

16. Sliwa S, Anzman-Frasca S, Lynskey V et al. (2016) Assessing the availability of healthier children's meals at leading quick-service and full-service restaurants. J Nutr Educ Behav 48, 242-249.e1.

17. Serrano EL \& Jedda VB (2009) Comparison of fast-food and non-fast-food children's menu items. J Nutr Educ Behav $\mathbf{4 1}$, 132-137.

18. Pereira MA, Ludwig DS, Bowman SA et al. (2004) Effects of fast-food consumption on energy intake and diet quality among children in a national household survey. Pediatrics 113, 112-118.

19. Paeratakul S, Ferdinand DP, Champagne CM et al. (2003) Fast-food consumption among US adults and children: dietary and nutrient intake profile. J Am Diet Assoc 103, 1332-1338.

20. Sato Y, Suzuki S, Chiba T et al. (2016) Factors associated with dietary supplement use among preschool children: results from a nationwide survey in Japan. $J$ Nutr Sci Vitaminol (Tokyo) 62, 47-53.

21. Hazano S, Nakanishi A, Nozue M et al. (2017) The relationship between household income and food intake of Japanese schoolchildren. Jpn J Nutr Diet 75, 19-28.

22. Adams J, Goffe L, Brown T et al. (2015) Frequency and socio-demographic correlates of eating meals out and takeaway meals at home: cross-sectional analysis of the UK national diet and nutrition survey, waves 1-4 (2008-12). Int J Behav Nutr Phys Act 12, 51.

23. Nikkei, Inc. (2016) Nikkei Gyokai Chizu 2016 (The Industry Map 2016 by Nikkei). Tokyo: Nikkei Publishing, Inc.

24. Toyo Keizai, Inc. (2017) Kaisha Shikiho Gyokai Chizu 2017 (The Industry Map 2017 by Kaisya Shikiho). Tokyo: Toyo Keizai, Inc. 
25. Harris JL, Pomeranz JL, Lobstein T et al. (2009) A crisis in the marketplace: how food marketing contributes to childhood obesity and what can be done. Annu Rev Public Health 30 , 211-225.

26. Longacre MR, Drake KM, Titus LJ et al. (2016) A toy story: association between young children's knowledge of fast food toy premiums and their fast food consumption. Appetite 96, 473-480.

27. Diez Roux A V (2002) A glossary for multilevel analysis. J Epidemiol Community Health 56, 588-594.

28. Asakura K \& Sasaki S (2017) SFA intake among Japanese schoolchildren: current status and possible intervention to prevent excess intake. Public Health Nutr 20, 3247-3256.

29. Zhou BF, Stamler J, Dennis B et al. (2003) Nutrient intakes of middle-aged men and women in China, Japan, United Kingdom, and United States in the late 1990s: the INTERMAP study. J Hum Hypertens 17, 623-630.

30. Asakura K, Uechi K, Masayasu S et al. (2016) Sodium sources in the Japanese diet: difference between generations and sexes. Public Health Nutr 19, 2011-2023.

31. Anderson CAM, Appel LJ, Okuda N et al. (2010) Dietary sources of sodium in China, Japan, the United Kingdom, and the United States, women and men aged 40 to 59 years: the INTERMAP study. J Am Diet Assoc 110, 736-745.

32. He FJ, Brinsden HC \& MacGregor GA (2014) Salt reduction in the United Kingdom: a successful experiment in public health. J Hum Hypertens 28, 345-352.
33. Block JP, Condon SK, Kleinman K et al. (2013) Consumers' estimation of calorie content at fast food restaurants: cross sectional observational study. BMJ 346, f2907.

34. Otten JJ, Saelens BE, Kapphahn KI et al. (2014) Impact of San Francisco's toy ordinance on restaurants and children's food purchases, 2011-2012. Prev Chronic Dis 11, E122.

35. Tandon PS, Zhou C, Chan NL et al. (2011) The impact of menu labeling on fast-food purchases for children and parents. Am J Prev Med 41, 434-438.

36. Ahn JY, Park HR, Lee K et al. (2015) The effect of providing nutritional information about fast-food restaurant menus on parents' meal choices for their children. Nutr Res Pract 9 , 667-672.

37. Dunford E, The Food Monitoring Group (2012) International collaborative project to compare and track the nutritional composition of fast foods. BMC Public Health 12, 559 .

38. Moran AJ, Block JP, Goshev SG et al. (2017) Trends in nutrient content of children's menu items in US chain restaurants. Am J Prev Med 52, 284-291.

39. Wu HW \& Sturm R (2014) Changes in the energy and sodium content of main entrées in US chain restaurants from 2010 to 2011. J Acad Nutr Diet 114, 209-219.

40. Rudelt A, French S \& Harnack L (2014) Fourteen-year trends in sodium content of menu offerings at eight leading fast-food restaurants in the USA. Public Health Nutr 17, $1682-1688$. 